\title{
Biomedical Cotton Waste Disposal Machine
}

\author{
Akash Vishwakarma, Nehal Gujar, Shubham Gurani , Samiksha Bhokare \\ DYPCOE Akurdi Pune
}

\begin{abstract}
The solution consists of converting the used cotton and gauze to flash/gun cotton and then burning it. The solution involves series of process. Drying is the first step. If the cotton/gauze is wet, it requires drying. After drying shredding is carried out to make cotton foamy. After this step, chemical solution is sprayed which converts the cotton to flash cotton. Example of solution is hydrochloric acid and potassium nitrate/nitric acid in proper proportion. Once we get flash cotton, the next step is the burning. Burning of flash cotton will not emit any hazardous fumes or gases. Pre requisites to carry out the above process includes sterilization of cotton/gauze to kill bacteria, virus and other non-sterile components on cotton.
\end{abstract}

\section{INTRODUCTION}

Currently the cotton and gauze waste generated in hospitals, clinic and other medical facilities involves a disposal procedure wherein a private or government body collects the waste and then disposes subsequently. This body charges hefty amount to hospitals for their service. The hospitals besides also needs to store the used cotton and gauze until the next collection drive takes place. If in a medical facility the generation of cotton waste is at very lower rate, the facility needs to store it for days until an appreciable amount of waste is generated and then send it for disposal. Storage of such cotton and gauze is hazardous from medical point of view.

Therefore, there is a need for solution that can immediately dispose the cotton waste at the source of its generation. Biomedical waste must be properly managed and disposed of to protect the environment, public and workers, especially healthcare and sanitation workers who are at risk of exposure to biomedical waste as an occupational hazard. The solution also needs to be an easy process to carry out in medical facility. The solution must be economical when compared to conventional disposal method.

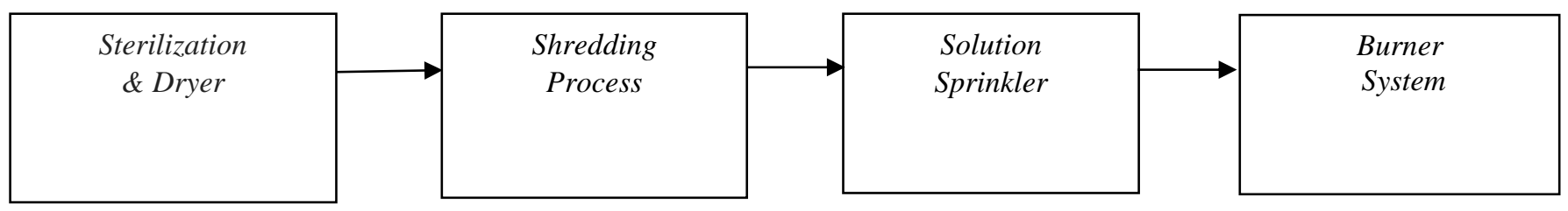

Block Diagram: Biomedical cotton waste disposal machine

\section{Block 1: Sterilization \& Dryer}

Sterilization refers to any process that removes, kills, or deactivates all forms of life (in particular referring to microorganisms such as fungi, bacteria, viruses, spores, unicellular eukaryotic organisms such as Plasmodium, etc.) Sterilization is distinct from disinfection, sanitization, and pasteurization, in that those methods reduce rather than eliminate all forms of life and biological agents present. After sterilization, an object is referred to as being sterile or aseptic .A pipe is attached to the lid of the shredding machine, which will be connected to the dryer container. In this container, the shredded cotton pieces will be placed with the help of suction created by the vacuum, which is attached outside the container. The dry cotton pieces will be forwarded to the solution sprinkler container.

\section{Block 2: Shredding Process}

It will be used to convert large pieces of cotton balls into smaller ones. Universal motor will be used for the shredding purpose. Universal motors have high starting torque, can run at high speed, and are lightweight and compact. They are commonly used in portable power tools and equipment, as well as many household appliances. They are also relatively easy to control, electromechanically using tapped coils, or electronically. Even when used with AC power these types of motors are able to run at a rotation frequency well above that of the mains supply, and because most electric motor properties improve with speed, this means they can be lightweight and powerful. However, universal motors are usually relatively inefficient: around 30\% for smaller motors and up to $70-75 \%$ for larger ones. Stainless steel dry grinding blade will be used to cut the large cotton balls into smaller pieces.

\section{Block 3: Solution Sprinkler}

Now the solution will be sprinkled on the dried cotton pieces to convert it into flash cotton so that it can be burnt easily. Nitrocellulose (also known as cellulose nitrate, flash paper, flash cotton, guncotton, and flash string) is a highly flammable compound formed by nitrating cellulose through exposure to nitric acid, or to a mixture of nitric acid and another acid, usually either hydrochloric acid or sulphuric acid, or to another powerful nitrating agent. One of its first major uses was as guncotton, a replacement for gunpowder as propellant in firearms. It was also used to replace gunpowder as a low-order explosive in mining and other applications. Nitrocellulose products are generally a mixture of mononitrocellulose, dinitrocellulose, 
and trinitrocellulose, where each glucose unit in the cellulose chain has one, two, or three nitro groups, respectively. There are several mono- and di- forms depending on which of the three slots have nitro groups. The flash cotton balls produced are dropped into the burning chamber.

\section{Block 4: Burner System}

In this system, the flash cotton balls produced will be burnt using a spark. By which the the cotton will burn within a second. At last, the smoke from burning cotton will pass through an air filter process, which will eject less polluted air to the surrounding.

\section{SCHEMATIC MODEL}

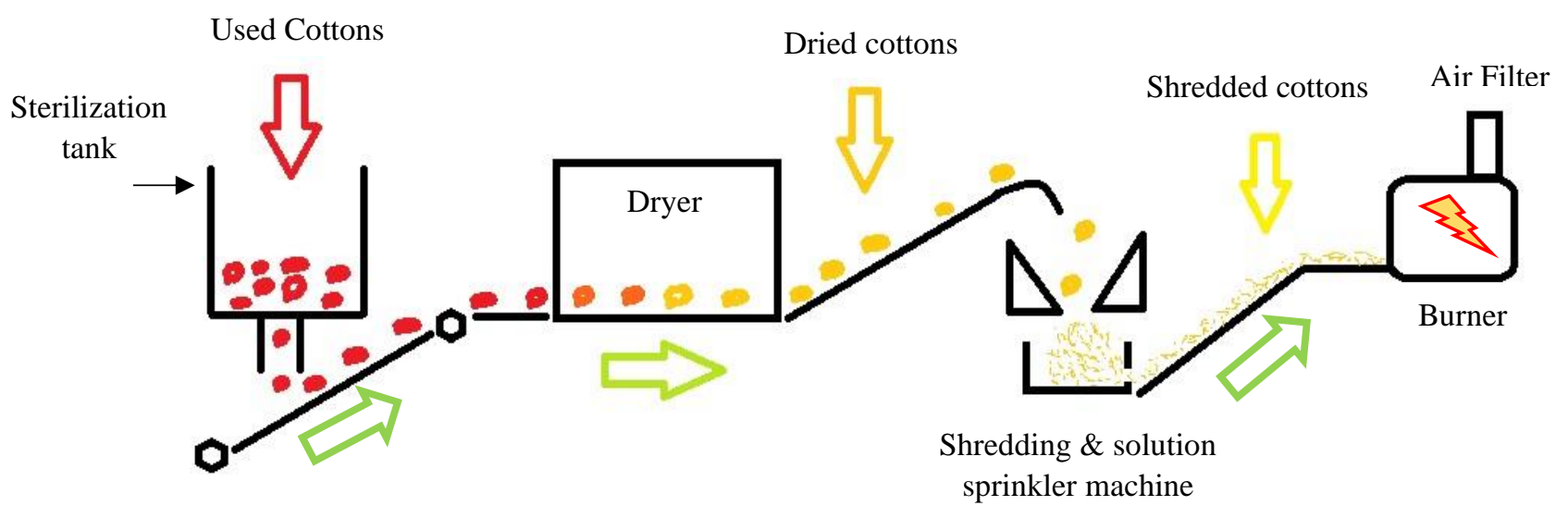

\section{CONCLUSION}

In this paper, a cotton disposal machine is being developed to dispose the biomedical waste cotton.

By sterilizing, drying, shredding \& burning. Purpose for making this machine is to start disposing biomedical cotton waste first at their own clinic and hospitals.

\section{REFERENCES}

[1] Lichtveld, M. Y.; Rodenbeck, S. E.; Lybarger, J. A. (1992). "The findings of the Agency for Toxic Substances and Disease Registry Medical Waste Tracking Act report". Environmental Health Perspectives. 98: 243-250. doi:10.1289/ehp.9298243. PMC 1519619. PMID 1486856.

[2] U.S. Congress, Office of Technology Assessment, Finding the Rx for Managing Medical Wastes, OTA-O-459 (Washington, DC: U.S. Government Printing Office, September 1990)

[3] "Bio Waste and Our Oceans". Secure Waste Disposal - Document Shredding \& Medical Waste Disposal. 2017-01-27. Archived from the original on 2019-04-15. Retrieved 2019-04-15.

[4] "Medical \& Bio-Hazard". Terragon Environmental Technologies Inc. Retrieved 2019-06-20.

[5] "NHS waste firm to sue health trusts over terminated contracts". BBC. 7 November 2018. Retrieved 13 November 2018. 